\title{
EVALUATING THE IMPACT OF AGEING POPULATION ON LABOUR MARKET
}

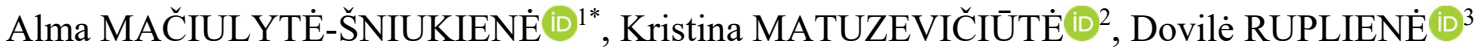 \\ ${ }^{I}$ Department of Business Technologies and Entrepreneurship, Faculty of Business Management, \\ Vilnius Gediminas Technical Unversity, Sauletekio al. 11, 10223, Vilnius, Lithuania \\ ${ }^{2}$ Department of Economic Engineering, Faculty of Business Management, \\ Vilnius Gediminas Technical Unversity, Sauletekio al. 11, 10223, Vilnius, Lithuania \\ ${ }^{3}$ Institute of Regional Development, Siauliai University, Visinskio str. 25, 76351, Siauliai, Lithuania
}

${ }^{*}$ E-mail: alma.maciulyte-sniukiene@vgtu.lt

\begin{abstract}
Purpose - ageing population causes a number of economic and social problems related to changes in the labour market. This study aims to evaluate the effect of the ageing population on the labour force which is the main indicator of the labour market in EU member states.

Research methodology - in order to achieve the aim of the study we applied the following methods: i) trend analysis to estimate and present population and changes of labour force over period, and ii) decomposition method to examine the effects of population and labour force structure in terms of age changes on size of labour force.

Findings - over the 2003-2017 period volume of the labour force has declined in Romania, Lithuania, Portugal, Latvia and Greece. This negative effect is influenced by both depopulation and structural changes in the workforce, including population ageing. Size of the labour force has increased in 23 countries, but in 11 of them, these positive changes were influenced by the rising of population activity, while depopulation it influenced negatively.

Research limitations - research results support the theoretical approach that ageing population may negatively affect the labour market but do not provide ways to solve this problem and this is the implication for further research.

Practical implications - the obtained results are useful for policymakers of the labour market (including pension reforms).

Originality/Value - the study contributes to scientific literature by sufficient understanding of ageing population problems that occur in labour market and fills the gap in research of ageing population impact on the labour market, using data of EU member states.
\end{abstract}

Keywords: ageing population, labour market, labour force, activity rate, decomposition.

JEL Classification: J11, J14, J21, J23.

Conference topic: Contemporary Issues in Economics Engineering.

\section{Introduction}

The increasing number of older population creates not only demographic imbalances but also social and economic consequences within society (Harper, 2014). The consequences of this process are complicated, multi-faceted and relative to individuals, families and society (Długosz, 2011). One of the most important aspects of an ageing population is the change in the nature of the labour force. As the total population is ageing, it is expected that the average age of employees will also increase significantly. The scale to which the ageing population is causing the ageing of the labour force depends on the age-specific participation rates, but current Eurostat forecasts suggest that a significant change in the workforce age is expected. According to ec.europa.eu (Being young..., 2017) projections based on Eurostat statistics, the median age of the EU-28 population will grow from 42.6 million in 2016 to 47 million in 2050. Moreover, the old-dependency ratio (the number of persons aged 65 years and over divided by the number of persons aged 15-64 years) will reach 49.4 per cent in 2050, while in 2016 it was 29.3 per cent. These projections clearly show the trends of ageing. As the needs and production capacities of different age groups are different, the country's economic characteristics are likely to change as the population is ageing. The standard approach for assessing these changes is to assume age-related behaviours to employment, consumption and savings, and to assess the key financial implications of changes in the relative size of different age groups. Expectations to live longer than

(C) 2019 Authors. Published by VGTU Press. This is an open-access article distributed under the terms of the Creative Commons Attribution (http://creativecommons.org/licenses/by/4.0/) License, which permits unrestricted use, distribution, and reproduction in any medium, provided the original author and source are credited. 
previous generations can encourage people to stay in the labour market for longer and start reducing savings at a later age, thus reducing potential aggregate demand. Moreover, older people have lower productivity and smaller potential to adopt new technology, which can negatively affect the performance of companies, especially in manufacturing. On the other hand, individualized services or products require experienced older workers, so early retirement can lead to undesirable consequences in light of this situation. Ageing also leads to lower income tax revenues and higher public expenditure, especially on health care and pensions.

Although, authors' approaches to the consequences of population ageing varied, there is presumably a general agreement that the ageing of the population will affect size and structure of the labour supply (Boersch-Supan, 2001; Kurkó, 2010; Toossi, 2012; Fuch, 2014; Fields, Uppal \& LaRochelle-Côté, 2017). The vast majority of the previous research analyse population age structure and/or ageing impact on economic growth in general (Fougère \& Mèrette, 1999; Prettner, 2013; Orlická, 2015; Abrigo, Racelis, Ian Salas \& Herrin, 2016; Maestas, Mullen \& Powell, 2016, Kasnauskienė \& Andriuškaitė, 2017), labour productivity (Boersch-Supan, 2001; Vandenberghe \& Waltenberg, 2010; Maestas et al., 2016), unemployment (Akanni \& Čepar, 2015; Kasnauskienė \& Andriuškaitė, 2017), wage level or labour cost (Boersch-Supan, 2001; Vandenberghe \& Waltenberg, 2010), income tax revenues and social security contributions (Dolls, Doorley, Schneider \& Sommer, 2014; Orlická, 2015; Prammer, 2018); changes of public expenditures (Balassone et al., 2011; Lisenkova, Mérette \& Wright, 2013; Orlická, 2015; European Commission, 2018), saving (Kasnauskienė \& Andriuškaitè, 2017) and consumption (Estrada, Park and Ramayandi, 2011; Stoever, 2012; Mao \& Xu, 2014; Kasnauskienė \& Andriuškaitė, 2017, Addessi, 2018). However, almost all these effects occur through changes in the labour market. Nevertheless, there is a lack of research in this area, especially the impact of the ageing population on the labour force, which is the main indicator of the labour market. Carone (2005) and Fields et al. (2017) investigate the impact of ageing population on overall labour market participation rate, which is the ratio of employed and unemployed people to the total working-age population (aged 15 and older); Fuch (2014) on labour supply; Balassone et al. (2011) - on size of the labour force. Research in this area is significant because countries are facing labour force shortages.

Seeking to fill this gap, this paper aims to shed light on the effects of population ageing occurring in labour market expressed as the changes in the labour force size. As labour force changes depend not only on changes in population structure by age but also on overall changes in the countries population, we focused on the impact of both indicators.

The paper is organized as follows: the First section provides a theoretical background on the impact of population ageing on the labour market. The second section presents the population and labour force trends of EU member states. The third section provides decomposition methodology, estimation results and discussion. The last section concludes the paper.

\section{Literature review on the impact of population ageing on the labour market}

The literature on population ageing impact on the labour market has identified a wide variety of potential issues and consequences. In this section, some of the main issues are reviewed. Changes in age structure not only have a negative economic impact, but also new opportunities. People have a longer and healthier life leading to longer years of work as well as different capacities and needs. These processes are analysed at all levels: individual, organizational and societal. Authors (Caron, Griffith \& Arcand, 2005; Serban, 2012; Orlická, 2015) distinguish two categories of the ageing population effects: (i) Direct effects: the size and quality of employment, capital/labour ratio and technical progress; (ii) Indirect effects: effects on budgets and, thus, on the whole economy.

A declining and ageing society is often considered to have a negative impact on economic growth and the labour market (Chesnais, 1998; Fina-Sanglas, 2000). The impact of ageing population on the labour market is reflected in the negative impact on labour volume, causing shortage of labour force, diminishing economic resources and increasing government spending needed to support older people for the health care and pensions, pressure on education systems, social and health insurance, higher taxes due to tension in social system, accumulation of pension funds may reduce other types of investment (Kanopienè \& Mikulionienè, 2006; WHO, 2012; Serban, 2012; Pettinger, 2013; Jowit, 2013). In addition, there is concern that older people will be recipients of state pensions for a longer period of time and will also benefit from savings in both private and national accounts (Lee \& Mason, 2011).

In the short term, positive effects can be expected by reducing costs for pre and postnatal leaves, child benefits, healthcare, education, in the long term, however, they increase the elderly dependency ratio (Serban, 2012). The concerns about the ageing population are encompassed with the "demographic deficit". This relates to the age structure transition method, which examines the composition of the population, taking into account the relationship between old and younger dependents with productive adults, and how this will change over time. In general, production capacity at different stages of the life cycle differs from the childhood dependency period to high productivity potential in adulthood and then returns to a decline in production capacity in old age. Macroeconomic effects will vary depending on the age composition of the population. The decline in the number of young people in the population is expected to reduce economic activity, and the increase in the number of older people is perceived as an economic burden due to higher expenditures for pensions and healthcare. The major reason for this concern is the assumption 
that older labour force will be less productive and less innovative in the future and that older people will have a lower ability to consumption. However, these contradictions are challenged by the argument that future generations with higher education, skills and training will be able to maintain a high level of productivity by supporting favourable work environment (Lee \& Mason, 2010). As Disney (1996) states, the increased level of experience can have a positive impact on productivity and this is caused by higher average levels of work experience. Relatively few adults acquire new formal qualifications that are over 25 years old. It is not surprising that economic models for returning to the economy show that financial incentives to acquire new qualifications are drastically reduced (OECD, 2001). Older workers are faced with higher alternative costs when they are learning, which takes time away from work because the earnings are higher. Incentives for work-related education or training for workers over 45 years old would improve the average length of work age by prolonging the return on investment in training. Participation in formal education can also be raised if the programs are designed to reduce the high alternative costs of older workers (OECD, 2001).

Research of Dixon (2003) reveals the downward pressure on economic activity levels of older workers. This is related to a higher number of older adults who are out of work and impact on aggregate levels of economic activity (Cabinet Office, 2000). The decline in the activity of older men over the past two decades has led to a major study of the reasons for early withdrawal from the labour market (Campbell, 1999; Disney, 1999, 1997; Pit \& Hansen, 2014; Korsakienè, Raišienė \& Bužavaitė, 2017). These studies show the complex set of factors influencing early retirement: work conditions (long work hours, higher psychological distress, low work satisfaction level) (Pit \& Hasen, 2014; Korsakienè et al., 2017; Böckerman \& Ilmakunnas, 2019), having pension coverage and health insurance coverage (Uccello, 2008), workers who have poor health (Uccello, 2008; Pit \& Hasen, 2014), improvements in middleage incomes and pre-retirement savings levels (Post, Schneer, Reitman \& Ogilvie, 2013; Zhao, 2018), and occupational pension schemes that allow members to draw pensions before the state pension age (Gustafson, 2017; Bogataj, Battini, Calzavara \& Persona, 2019). Greater provision of social security benefits to workers suffering from poor health or disability, and shifts in the industrial and occupational structure of employment that have reduced the demand for the skills held by older workers in manual jobs, have also played an important role. On the other hand, due to increased longevity and reforms in occupational pension schemes and other social security programmes, in order to reduce the incentives of early retirement, individuals are likely to increase the effective working age and participation rates (OECD, 1998). Others suggest that early withdrawal from work is influenced by rising real incomes and individuals' preferences to retire early (MacKellar, 2000). It is worth mentioning that some persons of retirement age choose bridge retirement instead of full retirement (Smaliukienė \& Tvarionavičienè, 2014).

The other impact aspect of an ageing population on the labour market is the relationship between age and income during the life cycle (Dixon, 2003). Employers' wage costs will most likely be increased by the ageing of the labour force if the current wage differences according to age structure are maintained (Johnson \& Zimmermann, 1993). The impact on unit labour costs will depend on whether average productivity increases with age. Older workers can be more productive, keeping in mind that older workers have more years of previous work experience (Disney, 1996). However, there is evidence that the positive relationship between age and wages is partly the result of an organizational wage policy aimed at promoting and rewarding good performance rather than a pure productivity effect (OECD, 1998). Organizational wage structures, which indirectly compensate for seniority, tend to increase wage costs, taking into account the ageing of the workforce and maybe accommodating (Johnson \& Zimmermann, 1993). As the labour force has been ageing for at least a decade, it may be that some companies are already making additional adjustments to their internal pay structures. The slow and gradual nature of the ageing labour force should provide considerable time for adaptation. In addition, it has been suggested that the ageing of the company's employees may lead to some sources of cost savings for employers, such as lower turnover costs and lower nonparticipation (Cabinet Office, 2000).

\section{An overview of population and labour force trends}

The research is based on the data related to 28 countries of the European Union for the period 2003-2017. Estimating the changes in the working age population over the analysed period, it is assumed that the working age of the population is 15-64. It was found that the number of population of this age group increased in 14 countries between 2003 and 2017. The biggest increase is observed in Luxembourg ( 35.5 per cent) and Cyprus (22.3 per cent), but the number of working-age population in these countries is about half a million and the absolute change is only 100 thousand. Malta can also be attributed to this type of country, where the number of working age population grew by 14.7 per cent, but the absolute increase was only about 40 thousand. The majority of the remaining countries with an increasing working age population are the old highly developed member states that have experienced significant immigration in recent years: Ireland, Sweden, the United Kingdom, Belgium, Austria, Spain, Denmark, and France. However, in Ireland, for example, the number of working-age population steadily increased over the period 20032009, stabilized for a short period, and since 2013, it has been growing again. In Sweden, the United Kingdom and Austria, the number of the working-age population grew throughout the analysed period. In Belgium, the number of this group of the population increased throughout the analysed period and only has slightly decreased in recent years. 
In Denmark, growth was stable, with a slight decrease only in the period 2011-2012. In Spain, the growth of the working age population is only observed until 2009, and in subsequent years, it has been declining. In France, this phenomenon has been observed since 2012 .

The analysis covers four countries, where the number of the working-age population decreased by more than 10 per cent between 2003 and 2017 - Latvia (20.4 per cent), Lithuania (19.6 per cent), Bulgaria (13.4 per cent), and Romania (12.3\%). It should be noted that the decline of the working age population is typical for the new member states that joined the European Union after 2004, including Greece and Portugal, which have been facing debt problems and economic slowdown in recent years. In Latvia, Lithuania, Bulgaria, Estonia and Hungary the decline of the working age population was stable throughout the analysed period, and in Romania, this process started only after its accession to the EU, in Poland, the Czech Republic, and Greece - since 2010, in Croatia - since 2012, in Slovenia since 2014, in Portugal - since 2008. Two countries - Finland and Italy - maintained almost the same number of working age population during the analysed period, with less than 1 per cent change.

The dynamics of the working-age population may be related to fundamental changes in the structure of this part of society. The working age population in this research is divided into 3 groups: aged 15-24, 25-54 and 55-64.

The main age group of the labour force is age 25-54, therefore, in assessing the impact of the ageing population on the labour market situation, the most important factor is the change of this age group. In 2017, the share of this age group exceeded 65 per cent only in four analysed countries. In the Czech Republic, Luxembourg and Spain it was 66.2-66.3 per cent, in Cyprus - 65.2 per cent. The smallest share of the working-age population aged $25-54$ is in the Netherlands, Finland and Croatia, where it reaches only 60.7-60.9 per cent. In 2003, the distribution of countries was different: although Luxembourg and Spain were among the leaders, the Netherlands, which faced a drastic decline of the share of population aged 25-54, during the analysed period, came into this group of countries. The Czech Republic was among the leaders in 2017 and it was only in the 20th place in 2003. Analysing the changes in the share of population aged 25-54 in 2003-2017, it was found that it has grown in 10 EU countries over the period. The biggest positive change is observed in the Czech Republic, Latvia and Bulgaria, this share has increased by 2.6-3.3 percentage point. The biggest negative change was recorded in the Netherlands, Denmark, France, Belgium, Finland and Luxembourg, where it was 2.0-4.9 percentage points. The Netherlands was recorded among the leaders in 2003, together with Finland it dropped to the bottom of the list, while Latvia from the bottom of the list was ranked in the 15th place. However, taking into account the absolute changes in the population of this age group, there are only two countries facing a significant increase - the United Kingdom and Spain, where the increase exceeded 1 million of the population. Over 300 thousand of the population in this group increased in Ireland and Sweden. However, even in 10 countries, the population of this age group has decreased by more than 300 thousand: Germany, Poland, Romania, Italy, the Netherlands, France, Bulgaria, Portugal, Lithuania and Hungary. In the first three countries, the decline exceeded 1 million.

Assessing the changes in the structure of the working age population, particularly important is the dynamics of population aged 15-24 and 55-64. The decline in the share of population aged 25-54 is less risky for the country's economy if the population share aged 15-24 is growing because it remains active in the labour market for several decades. The most dangerous is the situation where the share of the population aged 25-54 and 15-24 is decreasing, while the share of the population aged 55-64 is growing. There are 15 countries of this type: France, Belgium, Finland, Italy, Portugal, Lithuania, Austria, Germany, Croatia, Cyprus, Hungary, the United Kingdom, Slovenia, Poland and Spain. The exceptional situation is in the Netherlands and Denmark, where the decrease of the share of population aged 25-54 is compensated by the share of the population aged 15-24. Assessing the changes in the population aged $25-24$, it is stated that several countries experienced the highest losses: Poland ( -2.22 million), Romania (1.2 million) and Spain ( -0.97 million). This figure increased the most, amounting to 286 thousand in the United Kingdom.

Assessing the dynamics of the share of population aged 55-64 over the period 2003-2017, it can be seen that there was no country in 2003 where the share would exceed 20 per cent, the average rate was 16.5 per cent. Meanwhile, there were even 15 countries in 2017, with an average of 19.9 per cent. Croatia, Latvia, Slovenia, Germany, Poland and Lithuania (21.5-22.0 per cent) recorded the most significant values, Ireland, Luxembourg and Cyprus the lowest (16.5-17.8 per cent). This share decreased only in one country - Sweden $(-1.3$ percentage point), and the largest increase was recorded in Poland (7.9 percentage point), Slovakia (6.7 percentage point), Lithuania (6.2 percentage point) and Slovenia (6.1 percentage point). However, there is no country in which the population of this age group would decline. The highest growth was recorded in France, Poland, Spain, Italy, the United Kingdom and Germany, the number of this age group increased by 1-2 million over the analysis period. However, only in the United Kingdom the number of working-age populations has grown. In Spain, the population aged 25-54 grew, but the population aged 15-24 declined. Meanwhile, in Germany, Italy, Poland and France, with a rapidly growing population aged 55-64, the size of other working-age population decreased significantly over the analysed period.

The dynamics of the working age population in some countries has not resulted in the same changes in the economically active population (labour force). The number of the economically active population decreased only in five countries: Lithuania, Latvia, Romania, Portugal and Greece, but only in Lithuania and Latvia the decrease is more than 10 per cent. The significant increase is seen in Luxembourg (48 per cent), Malta (42 per cent) and Cyprus 
( 25 per cent), but as these countries have a low total population, such a high percentage increase in absolute terms is low: less than 100 thousand. However, in countries with a large population, such as the United Kingdom, Spain, Germany, France, labour force growth amounted to 2-3 million.

However, the analysis of the structure of the labour force by age group suggests that the increase in the labour force or at least the stability is usually related to the increase of the 55-64 age group. The share of labour force aged 15-24 increased in only 2 countries - Denmark (2.4 percentage point) and Sweden (1 percentage point). Although a slight absolute increase is also observed in Luxembourg, the Netherlands, Austria and Finland, it does not outweigh the increase in other structural parts. In two countries, Malta and Ireland, the structural decline in the youngest age group reaches 9 percentage point.

The main age group of the labour force is the population aged 25-54, countries ranged from 66 per cent (the Netherlands) up to 88 per cent (Luxembourg) in 2017, but only in 5 countries (Spain, Romania, Greece, Ireland and Malta), this share did not decrease since 2003. In Lithuania and the Netherlands, this structural share decreased the most, by over 7 percentage points. The absolute change in the active population of this age group in 14 countries was positive, but only in Malta, Luxembourg, Ireland, Cyprus, Spain, Sweden and the United Kingdom it exceeded 10 per cent. Lithuania (21 per cent) and Latvia (14 per cent) lost most of the labour force of this age group.

The structural part of the population aged 55-64 decreased only in Sweden over the period 2003-2017, but the decline was only 0.4 percentage point. The largest increase was in Slovakia (from 5.2 to 15.2 per cent), Lithuania (from 11.0 to 20.2 per cent) and Poland (from 6.5 to 15.5 per cent), but the highest share of the population aged $55-$ 64 was in Lithuania, Germany and Latvia. The lowest values were in Luxembourg, Malta, and Slovenia.

\section{Decomposing labour force growth}

The volume of the labour force may change for two reasons: the population of working-age groups and the level of activity of these groups. The dynamics of these indicators may depend on a number of additional factors: fertility and mortality, migration, level of health protection, economic structure, social protection, etc. In order to assess how the workforce changed in the 28 EU countries over the period 2003-2017, the decomposition method was used for analysis. The decomposition method to assess the effects of population and participation changes or other demographic changes on labour force was used by Carone (2005), Hotchkiss (2009), Dolls et al. (2014), Fuchs (2014), Fields et al. (2017), and Seshadri (2018).

The total labour force $L_{t}$ is divided into i groups by age. $L_{x t}$ is the labour force at time $\mathrm{t}$ for group $\mathrm{x}, \mathrm{A}_{\mathrm{xt}}$ is the group-specific labour participation rate and $\mathrm{P}_{\mathrm{xt}}$ is the population of group $\mathrm{x}$. The total labour force at time $t$ is given by summing over the subscript $\mathrm{x}$.

$$
L_{t}=\sum L_{x t}=\sum A_{x t} P_{x t}, \text { where } x=1,2, \ldots \mathrm{i} .
$$

The change in the labour force $(\Delta \mathrm{Lt})$ between a year $\mathrm{t}$ and the base year $(\mathrm{t}=0)$ can be decomposed as follows:

$$
\Delta L=A_{0}\left(P_{t}-P_{0}\right)+P_{1}\left(A_{t}-A_{0}\right) .
$$

The first term of (2) shows the population effect due to changes in size and structure of the population when agespecific participation rates remain constant (the base year 2003). The total population effect at time $t$ is calculated by summing the effects over all groups.

\section{Population component:}

$$
A_{0}\left(P_{t}-P_{0}\right)
$$

The second part of (2) is the participation rate effect due to changes in the age-specific participation rates, given the population from the base year 2017 of the projection. The total participation effect is obtained by summing the effects over all groups.

\section{Participation component:}

$$
P_{1}\left(A_{t}-A_{0}\right)
$$

The carried out analysis showed that the trends of the total size of the working age population and the population of the main age groups do not correspond to the trends of the volume of the labour force and the volume of the structural parts. In order to assess which of the direct factors influenced the changes in the labour force to a greater extent, the decomposition method was used, allowing to separately measure the change in the volume of labour force due to the change of population in the evaluated age groups (equation (3)) and the change in the activity rates of the population of these age groups (Eq. (4)). The results of the research showed that the analysed countries can be divided into three groups, according to the changes in the labour force over the period 2003-2017: (1) countries where the volume of labour force has increased both as a result of population growth and an increase in the activity rates; (2) countries with an increasing labour force, despite a declining population, but the positive impact of activity rate growth 
has outweighed' the negative impact of population decline; (3) countries with a declining labour force due to depopulation, and the positive impact of the activity rate was not high enough to outweigh the negative impact of population decline. Table 1 shows the countries that were submitted to the first group.

Table 1. Decomposition of the change in labour force: I group of the countries (source: authors calculations based on Eurostat data)

\begin{tabular}{|c|c|c|c|}
\hline & $\begin{array}{c}\text { Change in the labour } \\
\text { force, thousands }\end{array}$ & $\begin{array}{c}\text { Labour force change due to } \\
\text { population change, thousands }\end{array}$ & $\begin{array}{c}\text { Change in labour force due to change in } \\
\text { the activity rates level, thousands }\end{array}$ \\
\hline United Kingdom & 3168 & 2167 & 1001 \\
\hline Spain & 2925 & 1123 & 1802 \\
\hline France & 1775 & 317 & 1458 \\
\hline Sweden & 690 & 367 & 323 \\
\hline Belgium & 531 & 181 & 350 \\
\hline Austria & 500 & 193 & 307 \\
\hline Ireland & 337 & 302 & 35 \\
\hline Slovakia & 112 & 27 & 85 \\
\hline Luxembourg & 92 & 64 & 28 \\
\hline Denmark & 86 & 80 & 6 \\
\hline Cyprus & 84 & 74 & 10 \\
\hline Malta & 66 & 21 & 45 \\
\hline
\end{tabular}

In the United Kingdom, Spain and France the increase in the labour force over the analysis period exceeded 1.7 million. However, changes in the working age population and the level of activity have led to the varying scope of change. In the United Kingdom, 2/3 of the increase in the workforce was determined by population growth and it is worth noting that the population of all age groups has grown. It is also worth noting that in this country the activity rate was the fourth largest among 28 EU countries, while in 2017 it was ranked as the fifth and differed from the first place only slightly. It can be said that this country is not facing the negative impact of an ageing population on the labour market as the working age population and activity rate are increasing at the same time. The only danger that can be perceived in this country is that the activity rate is decreasing in the youngest age group of 15-24. In Spain and France, the significant increase in the working age population was recorded, but growth was slower in France. However, while in both countries the population aged 15-24 has declined, France has been less affected by this. Another difference is that Spain did not face a decrease in the population aged 25-54, and in France, albeit with a slight but decreasing trend. Meanwhile, the population aged 55-64 grew by about a third in both countries. There are also differences in activity rates. This indicator increased by 5.8 per cent in Spain over the period 2003-2017, in France 2.1 percentage point.

Analysing other countries in this group, we can see that the old member states of the European Union are dominating. Among them, there are only three countries that joined the EU after 2004 - Slovakia, Cyprus and Malta, but the situation in Cyprus and Malta is specific according to the low population and the economic structure of these countries.

Table 2 shows the countries where the labour force has increased, but it was determined only by an increase in activity levels. This group of countries is very heterogeneous, with both new and old member states, also in terms of changes in the labour force, in the working-age population and inactivity rates. In Germany and Italy, the labour force has increased by over 1.5 million, the negative impact of the decline in the working age population was significantly lower than the positive impact of the activity rate. The unifying feature of these countries is the fact that the population aged 55-64 has grown, while the population in other age groups has decreased. In Germany, the activity rate increased by 6.1 per cent, while the change in Italy was only 3.9 percentage point. This indicator was in the fourth place from the bottom of the list, and in 2017 it has become the smallest among 28 EU countries. While this shows the problem of the Italian labour market, on the other hand, it can also be seen as an additional untapped potential in the future.

Exceptional in this group is Poland's position. Despite an increase in the labour force of 0.276 million, the working age population significantly decreased, falling by 37 per cent in the age group of 15-24, and 7 per cent in the age group of 25-54 and only in the age group of 55-64 it increased by 47 per cent. The level of activity rate in this country increased by 5.6 percentage point, but it still remains one of the smallest in the EU.

In the Netherlands and Hungary, the labour force increased by 0.5 million. However, in the Netherlands, this increase was largely driven by an increase in activity rates, with a negligible impact of the working age population. In this country, the number of people aged 25-54 has slightly decreased, but as the population, aged 15-24 has 
grown, the problem of the decline of the working age population is milder. Meanwhile, only the population aged 5564 has grown in Hungary, but this country has experienced an impressive increase in activity rates of 10.6 percentage points. This indicator was the second from the end in Hungary in 2003, and in 2017 only slightly lagged behind the group average. As a result of a similar change in the indicators, Bulgaria was also affected in this group of countries, which, despite significant losses in the working age population, was able to outweigh the negative impact of population decline. In the remaining countries, labour force growth was modest, but the positive change was driven by activity rate growth.

Table 2. Decomposition of the change in labour force: II group of the countries (source: authors' calculations based on Eurostat data)

\begin{tabular}{|c|c|c|c|}
\hline & $\begin{array}{c}\text { Change in the labour } \\
\text { force, thousands }\end{array}$ & $\begin{array}{c}\text { Labour force change due to } \\
\text { population change, thousands }\end{array}$ & $\begin{array}{c}\text { Change in labour force due to change in } \\
\text { activity rates, thousands }\end{array}$ \\
\hline Germany & 2663 & -911 & 3574 \\
\hline Italy & 1542 & -251 & 1793 \\
\hline Netherlands & 455 & -83 & 538 \\
\hline Hungary & 424 & -273 & 697 \\
\hline Poland & 276 & -1243 & 267 \\
\hline Czech Republic & 204 & -63 & 109 \\
\hline Slovenia & 67 & -42 & 120 \\
\hline Croatia & 66 & -54 & 104 \\
\hline Finland & 56 & -48 & 411 \\
\hline Bulgaria & 44 & -367 & 57 \\
\hline Estonia & 14 & -43 & \\
\hline
\end{tabular}

Table 3 shows the countries that have faced a decline in the labour force and this is due to the decline in the working age population. Although an increase in activity rates was recorded in all countries of this group, its positive effect was not sufficient to offset the negative impact of population change.

Table 3. Decomposition of the change in labour force: III group of the countries (source: authors' calculations based on Eurostat data)

\begin{tabular}{|c|c|c|c|}
\hline & $\begin{array}{c}\text { Change in the labour } \\
\text { force, thousands }\end{array}$ & $\begin{array}{c}\text { Labour force change due to } \\
\text { population change, thousands }\end{array}$ & $\begin{array}{c}\text { Change in labour force due to change in } \\
\text { activity rates, thousands }\end{array}$ \\
\hline Romania & -481 & -1058 & 577 \\
\hline Lithuania & -203 & -308 & 105 \\
\hline Portugal & -133 & -269 & 136 \\
\hline Latvia & -118 & -195 & 77 \\
\hline Greece & -29 & -212 & 183 \\
\hline
\end{tabular}

Romania has suffered the biggest reduction in the labour force: it reached nearly half a million over the period 2003-2017. This change was due to the decline in the working age population, which occurred both in the 15-24 age group ( -36 per cent) and in the $25-54$ age group ( -11 per cent). Only the number of population aged 55-64 grew by 20 per cent. In the youngest group aged 15-24 the number of the population decreased as well as the rate of activity, therefore, the number of the active population decreased by 46 per cent. In the population group, aged 25-54 growth in activity rate did not compensate for the decline in population, resulting in a decrease in the number of economically active people by 5 per cent. In terms of activity rate, Romania is in the fourth place from the bottom of the list, so it is likely that future growth in activity rate may help mitigate the negative impact of population decline.

Lithuania has also suffered a significant reduction in the labour force. In addition, although the labour force has decreased less than in Romania, the rate of decline is the highest of all 28 EU countries (-12.6 per cent). Lithuania lost its population both in the youngest group aged 15-24 (-37 per cent) and in the main group aged 25-54 years $(-21.4 \%)$, the number of the population grew only in the group aged 55-64 (11 per cent). These changes were partly compensated by changes in activity rates, which were positive in all age groups. In contrast to Romania, the activity rate in Lithuania grew in the youngest age group, although it still lags far behind the EU average. In the group aged 25-54, the activity rate was one of the highest for the analysed period in Lithuania, although in 2003 it was the second largest, in 2017 it was only the fourth. This shows that the main labour force in Lithuania has no potential to grow unless the decrease of population in this age group is slowed down. The activity rate of the group aged 55-64 
over the analysed period experienced a big jump from 50.5 per cent to 71.3 per cent and exceeded the EU average in 2017.

In Portugal, the labour force dropped by 133 thousand over the period 2003-2017, but the decline only started in 2010. Population decline in this country began in 2009 and steadily decreased until 2017. The number of population of different age groups varies unevenly: in the group aged 15-24 the number of the population decreased by 19.5 per cent, in the age group of 25-54 - by 7.1 per cent, but in the age group of 55-64 it increased by 21 per cent. This situation shows the ageing population and puts the country's labour market at risk, especially as the activity rate has increased by only 2 percentage points over the analysed period. The increase was achieved mainly by the growth of activity rate by population aged 25-54. It should be noted that the activity of both populations aged 25-54 and 5564 exceeds the EU average in 2017, but in the youngest age group it declined throughout the analysed period and is no longer reaching the EU average.

The decline in the Latvian labour force is at a similar level as in Portugal, but the overall increase in activity rate was higher. In Latvia, the activity rate increased in all age groups, while in the group aged 55-64 the increase was 20.5 percentage point. The main problem in Latvia is the decrease of the population, in this respect, only Lithuania is ahead of Latvia. The population aged 15-24 has been decreasing every year since 2005; the population aged 25-54 - since the beginning of the analysed period. The only working-age population that grew in size was aged 5564, but the increase was just 2 per cent and it exceeded only the Swedish indicator. In this respect, Latvia's situation is exceptional and the risks to its labour market are related both to the decline in the labour force and to its ageing.

\section{Conclusions}

The impact of population ageing is usually described as an increase in the ratio of the number of individuals of pension age and a decrease in the number of individuals of working age, e.g. an increase in median age of the population. It can cause negative social and economic consequences: rising tension in the social security system, decrease of average productivity level, a decrease of income tax revenues and an increase of public expenditures, lower saving rates and consumption, which may limit economic growth. Population ageing leads to labour market imbalance within changes on size and structure of the labour supply and shortage of labour force.

The research results allowed to assess the changes in the workforce in the past 15 years in all the present EU countries, to identify the main trends of change, to distinguish similarities and differences between countries, to group countries according to the impact of the working age population and labour force on labour force change. The analysis of EU member states population and labour force trends over the period 2003-2017 revealed that the number of working-age people has increased in fourteen countries. The decrease in the working age population is the trend of the new member states that joined the EU after 2004. In five of these countries (Greece, Latvia, Lithuania, Portugal and Romania) has decreased not only working for the age population but also the size of the active population. These countries are also facing a decline in the overall amount of the labour force.

Labour force changes mainly depend on: (i) overall changes of countries'working-age population; (ii) changes of working age population structure by age; (iii) changes of activity rate in age-specific groups. Using the decomposition technique, we assessed these effects. Estimation results revealed that labour force over the period 2003-2017 increased in 12 countries (the United Kingdom, Spain, France, Sweden, Belgium, Austria, Ireland, Slovakia, Luxembourg, Denmark, Cyprus and Malta) due to increase in both sizes of working age population and activity rate. Labour force also increased in Germany, Italy, the Netherlands, Hungary, Poland, the Czech Republic, Slovenia, Croatia, Finland, Bulgaria, Estonia, but this change was positively influenced only by population growth. Working-age population in those countries has decreased and share of the older population in its structure has increased. These processes influenced the size of labour force negatively. In five EU member states, size of the labour force has decreased: in Romania by 481 thousand, in Lithuania by 203 thousand, in Portugal by 133 thousand, in Latvia by 118 thousand, and in Greece by 29 thousand. This negative effect was influenced mainly by the decrease in population.

The limitations of the research are related to the fact that only the changes in the labour force and their relation to the two main factors were assessed in the paper. For a deeper analysis, it is also appropriate to assess the causes of the ageing population in the countries, including the level of migration, as well as the deeper analysis of the activity rates in the countries and the underlying causes. In view of the scale of the EU immigration problem in recent years, the results of such research are of great practical importance for the development of migration policy.

\section{Disclosure statement}

We declare that we do not have any competing financial, professional, or personal interests from other parties. 


\section{References}

Abrigo, R. M., Racelis, R. H., Ian Salas, J. M., \& Herrin, A. N. (2016). Decomposing economic gains from the population age structure transition in the Philippines. The Journal of the Economics of Ageing, 8, 19-27. https://doi.org/10.1016/j.jeoa.2016.09.002

Addessi, W. (2018). Population age structure and consumption expenditure composition: Evidence from European countries. Economics Letters, 168, 18-20. https://doi.org/10.1016/j.econlet.2018.03.033

Akanni, M. T., \& Čepar, Ž. (2015). Impact of population ageing on unemployment and entrepreneurial activity: The case of Slovenia. Organizacija, 48(4), 232-245. https://doi.org/10.1515/orga-2015-0020

Balassone, F., Cunha, J., Langenus, G., Manzke, B., Pavot, J., Prammer, D., \& Tommasino, P. (2011). Fiscal sustainability and policy implications: a post-crisis analysis for the euro area. International Journal of Sustainable Economy, 3(2), 210-234. https://doi.org/10.1504/IJSE.2011.039441

Boersch-Supan, A. (2001). Labour market effects of population ageing (NBER Working Paper 8640). Cambridge: National Bureau of Economic Research. https://doi.org/10.3386/w8640

Bogataj, D., Battini, D., Calzavara, M., \& Persona, A. (2019). The ageing workforce challenge: Investments in collaborative robots or contribution to pension schemes form the multi-echelon perspective. International Journal of Production Economics, 210, 97-106. https://doi.org/10.1016/j.ijpe.2018.12.016

Böckerman, P., \& Ilmakunnas, P. (2019). Do good working conditions make you work longer? Analyzing retirement decisions using a linked survey and register data. The Journal of the Economics of Ageing, In Press, Accepted Manuscript. https://doi.org/10.1016/j.jeoa.2019.02.001

Cabinet Office (2000). Winning the generation game: Improving opportunities for people aged 50-65 in work and community activity. London: Cabinet Office.

Campbell, N. (1999). The decline in employment among older people in Britain (Centre for Analysis of Social Exclusion Paper No. 19). London: London School of Economics.

Caron, C. D., Griffith, J., \& Arcand, M. (2005). Decision making at the end of life in Dementia: How family caregivers perceive their interactions with health care providers in long-term-care settings. Journal of Applied Gerontology, 24(3), 231-247. https://doi.org/10.1177/0733464805275766

Carone, G. (2005). Long-term labour force projections for the 25 EU member states: A set of data for assessing the economic impact of ageing (November 2005). European Commission Economic Paper No. 235 . Retrieved from https://ssrn.com/abstract=871086 or https://doi.org/10.2139/ssrn.871086

Chesnais, J. C. (1998). Below-replacement fertility in the European Union (EU-15): Facts and policies, 1960-1997. Review of the Population and Social Policy, 7(101), 83-101.

Disney, R. (1996). Can we afford to grow older? A perspective on the economics of ageing. Cambridge, Massachusetts: MIT Press.

Disney, R. (1997). The dynamics of retirement: Analyses of the retirement surveys (Department of Social Security Research Report No. 72). London: HMSO.

Disney, R. (1999). Why have older men stopped working? In P. Gregg \& J. Wadsworth (Eds.), The state of working Britain (pp. 58-74). Manchester: Manchester University Press.

Dixon, S. (2003). Implications of population ageing for the labour market. Labour Market Trends, 111(2), 67-76.

Długosz, Z. (2011). Population ageing in Europe. The $2^{\text {nd }}$ International Geography Symposium GEOMED2010. Procedia Social and Behavioral Sciences, 19(2011), 47-55. https://doi.org/10.1016/j.sbspro.2011.05.106

Dolls, M., Doorley, K., Schneider, H., \& Sommer, E. (2014). Demographic change in Europe: The labour market and fiscal effects in 2030. Retrieved from http://www.neujobs.eu/sites/default/files/event/2014/07/Demographic\%20change\%20in\%20Europe.pdf

Ec.europa.eu (2017). Being young in Europe today - demographic trends. Retrieved from https://ec.europa.eu/eurostat/statisticsexplained/index.php/Being_young_in_Europe_today_-_demographic_trends\#Europe.27s_demographic_challenge

Estrada, G., Donghyun, P., \& Erief, R. (2011). Population ageing and aggregate consumption in developing Asia (ADB Economic Working Paper Series No. 282). Mandaluyong City, Philippines: Asian Development Bank.

European Commision (2018). The 2018 ageing report: Economic and budgetary projections for the EU member states (20162070). Retrieved from https://ec.europa.eu/info/sites/info/files/economy-finance/ip079_en.pdf

Fields, A., Uppal, S., \& LaRochelle-Côté, S. (2017). The impact of ageing on labour market participation rates. Statistics Canada. Minister of Industry. Retrieved from https://www150.statcan.gc.ca/n1/pub/75-006-x/2017001/article/14826-eng.htm

Fina-Sanglas, L. (2000). Europe's population and labour market beyond 2000: Main issues and policy implications. In A. Punch \& D. L. Pearce (Eds.), Europe's population and labour market beyond 2000, population studies (33, pp. 43-111). Strasbourg, France: Council of Europe.

Fougère, M., \& Mèrette, M. (1999). Population ageing and economic growth in several OECD countries. Economic Modelling, 16, 411-427. https://doi.org/10.1016/S0264-9993(99)00008-5

Fuchs, J. (2014). Decomposing the effects of population ageing on labour supply. Athens Journal of Social Science, 2(2), 109126. https://doi.org/10.30958/ajss.2-2-3

Gustafson, P. (2017). The gendered economics of synchronized retirement. Research on Aging, 40(7): 623-644. https://doi.org/10.1177/0164027517724491 
Harper, S. (2014). Economic and social implications of ageing societies. Science, 346(6209), 587-591. https://doi.org/10.1126/science. 1254405

Hotchkiss, J. L. (2009). Changes in the aggregate labor force participation rate. Economic Review, 94(4), 1-6. https://doi.org/10.2139/ssrn.1433124

Johnson, P., \& Zimmerman, K. (1993). Ageing and the European labour market: public policy issues. In P. Johnson \& K. Zimmermann (Eds.), Labour markets in an ageing Europe. Cambridge: Cambridge University Press. https://doi.org/10.1017/CBO9780511983313.002

Jowit, J. (2013). An ageing population will have a huge impact on social services. The Guardian. Retrieved from $\mathrm{http}: / /$ www.theguardian.com/society/2013/feb/24/britain-ageing-population-lords-inquiry

Kanopienè, V. \& Mikulionienè, S. (2006). Population ageing and its Challenges to the Health Care System. Gerontologija, 7(4), $188-200$.

Kasnauskienè, G., \& Andriuškaitè, M. (2017). Economic implications of ageing Lithuanian population. Organizations and Markets in Emerging Economies, 8(1), 44-62.

Korsakienė, R., Raišienė, A. G., \& Bužavaitė, M. (2017). Work engagement of older employees: do employee and work-related factors matter? Economics and Sociology, 10(4), 151-161. https://doi:10.14254/2071-789X.2017/10-4/12

Kurkó, I. (2010). The influence of demographic aging on the potential labour market supply. Journal of Settlements and Spatial Planning, 1(2), 117-124.

Lee, R., \& Mason, A. (2011). Population aging and the generational economy: A global perspective. Cheltenham, UK: Edward Elgar. https://doi.org/10.4337/9780857930583

Lee, R., \& Mason, A. (2010). Fertility, human capital, and economic growth over the demographic transition. European Journal of Population/Revue européenne de Démographie, 26(2), 159-182.

Lisenkova, K., Mérette, M., \& Wright, R. (2013). Population ageing and the labour market: Modellingsize and age-specific effects. Economic Modelling, 35, 981-989. https://doi.org/10.1016/j.econmod.2013.09.007

MacKellar, F. L. (2000). The predicament of population aging: A review essay. Population and Development Review, 26(2), 365404. https://doi.org/10.1111/j.1728-4457.2000.00365.x

Maestas, N., Mullen, K. J., \& Powell, D. (2016). The effect of population aging on economic growth, the labor force and productivity (NBER Working Paper No. 22452). Cambridge: National Bureau of Economic Research.

Mao, R., \& Xu, J. (2014). Population ageing, consumption budget allocation and sectoral growth. China Economic Review, 30 , 44-65. https://doi.org/10.1016/j.chieco.2014.05.004

OECD. (1998). Work-force ageing (OECD Employment Outlook 1998). Paris, France: OECD.

OECD. (2001). Investment in human capital through post-compulsory education and training (OECD Economic Outlook 2001). Paris, France: OECD.

Orlická, E. (2015). Impact of population ageing and elderly poverty on macroeconomic aggregates. Procedia Economics and Finance, 30(2015), 598-605. https://doi.org/10.1016/S2212-5671(15)01272-1

Pettinger, T. (2013). The impact of an ageing population on the economy. Economics help revision. Retrieved from http://www.economicshelp.org/blog/8950/society/impact-ageing-population-economy/

Pit, S. W., \& Hansen, V. 2014. Factors influencing early retirement intentions in Australian rural general practitioners. Occupational Medicine, 64(4), 297-304. https://doi.org/10.1093/occmed/kqu028

Post, C., Schneer, J. A., Reitman, R., \& Ogilvie, D. (2013). Pathways to retirement: A career stage analysis of retirement age expectations. Human Relations, 66(1), 87-112. https://doi.org/10.1177/0018726712465657

Prammer, D. (2018). How does population ageing impact on personal income taxes and social security contributions? The Journal of the Economics of Ageing. In Press, Accepted Manuscript. https://doi.org/10.1016/j.jeoa.2018.12.005

Prettner, K. (2013). Population ageing and endogenous economic growth. Journal of Population Economics, 26(2), 811-834. https://doi.org/10.1007/s00148-012-0441-9

Serban, A. C. (2012). Ageing population and effects on the labour market. International Conference on Applied Economics (ICOAE) 2012. Procedia Economics and Finance, 1(2012), 356-364. https://doi.org/10.1016/S2212-5671(12)00041-X

Seshadri, A. (2018). A Meta-analysis of the decline in the labor force participation rate (MRRC Working Paper WP 2018-381). Michigan, USA: University of Michigan Retirement Research Center.

Smaliukienė, R., \& Tvarionavičienè, M. (2014). Bridge employment: an opportunity for ageing society. Procedia - Social and Behavior Sciences, 156(2014), 388-391.

Stoever, B. (2012). The influence of Age on Consumption. EconPaper No. 3808. Retrieved from https://econpapers.repec.org/paper/ekd002672/3808.htm

Toossi, M. (2012). Labour force projections to 2020: a more slowly growing workforce. Monthly labour review / U.S. Department of Labor, Bureau of Labor Statistics, 135(1), 43-64.

Uccello, C. E. (2008). Factors influencing retirement: Their implications for raising retirement age. Washington: AARP.

Vandenberghe, V., \& Waltenberg, F. (2010). Ageing workforce, productivity and labour costs of Belgian firms (IRES Discussion Paper 2010-3). Retrieved from https://core.ac.uk/reader/6270771

WHO. (2012). Global health and aging. Retrieved from http://www.who.int/ageing/publications/global_health.pdf

Zhao, B. (2018). Too poor to retire? Housing prices and retirement. Review of Economic Dynamics, $27,27-47$. https://doi.org/10.1016/j.red.2017.11.002 